\title{
EFFECTS OF DIET AND PHYSICAL ACTIVITY ON ADIPOSITY AND BODY FAT DISTRIBUTION : IMPLICATIONS FOR THE PREVENTION OF CARDIOVASCULAR DISEASE
}

\author{
JEAN-PIERRE DESPRÉS AND BENOÎT LAMARCHE \\ Lipid Research Center, Laval University Medical Research Center, Ste-Foy, Quebec, \\ Canada
}

\section{CONTENTS}

INTRODUCTION

PREVALENCE OF OBESITY . . . . . . . . . . . . . . . . . 138

HEALTH HAZARDS OF OBESITY . . . . . . . . . . . 138

BODY FAT DISTRIBUTION, INSULIN RESISTANCE,

REGIONAL ADIPOSE TISSUE DISTRIBUTION AND PLASMA

ADIPOSE TISSUE DISTRIBUTION AND HYPERTENSION . . . . $\quad . \quad 142$

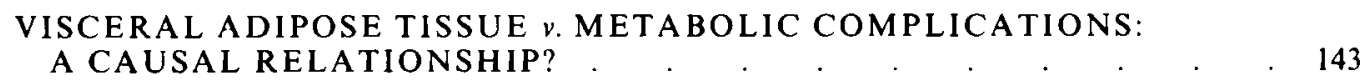

CONTRIBUTIONS OF LACK OF PHYSICAL ACTIVITY AND A HIGH

FAT DIET TO THE AETIOLOGY OF OBESITY AND RELATED

COMPLICATIONS .

TREATMENT OF OBESITY AND RELATED COMPLICATIONS. • . 146

DIET . . . . . . . . . . . . . . . . . . . . 146

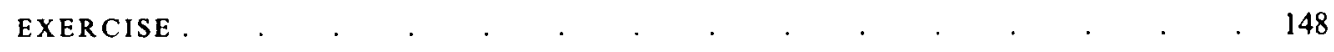

THERAPEUTIC IMPLICATIONS . . . . . . . . . . . . . . . . $\quad . \quad 152$

REFERENCES . . . . . . . . . . . . . . . . . . 153

\section{INTRODUCTION}

It is widely accepted that obesity is detrimental to health (Bray, 1985; NIH Consensus Development Panel on the Health Implications of Obesity, 1985; Kissebah et al. 1989) and a higher prevalence of non-insulin-dependent diabetes mellitus (NIDDM), dyslipidaemia, hypertension and of cardiovascular diseases (CVD) is observed among obese patients (Van Itallie, 1979; Larsson et al. 1981; Bray, 1985; Kissebah et al. 1989) in comparison with individuals of normal weight. Furthermore, recent analyses from prospective studies have confirmed the moderate but significant association between obesity and mortality related to cardiovascular diseases (Rabkin et al. 1977; Hubert et al. 1983; Barrett-Connor, 1985;

Address correspondence to: Jean-Pierre Després, Ph.D., Professor and Associate Director, Lipid Research Center, Laval University Medical Research Center, CHUL, 2705 Laurier Boulevard, Ste-Foy, Quebec, Canada GIV 4G2. 
Terry et al. 1992). As a general rule, studies with large cohort sizes and with follow-up periods of more than 10 years have reported that obesity is a significant predictor of mortality related to CVD (Harrison, 1985). Among factors involved in the development of obesity, reduced physical activity and excess caloric intake, especially increased consumption of food with a high content of saturated fat, have been suggested as contributory factors in the increased prevalence of obesity reported in developed countries; in contrast, the prevalence of obesity has been reported to be low in populations consuming a low fat diet, such as in Japan thirty years ago (Lands et al. 1990). The objective of this article is to review the evidence on the role of diet and exercise in the regulation of body composition, abdominal adipose tissue accumulation and related metabolic complications. Therapeutic implications will also be discussed.

\section{PREVALENCE OF OBESITY}

There is no doubt that the prevalence of obesity has increased during this century in developed countries (Danforth, 1985). In a random sample of the Canadian population (26293 men and women aged 18-74 years) surveyed in 1986-90 (Reeder et al. 1992), 35\% of men and $27 \%$ of women had body mass index (BMI) values above $27 \mathrm{~kg} / \mathrm{m}^{2}$. The mean BMI of subjects aged $45-54$ was $27 \mathrm{~kg} / \mathrm{m}^{2}$ in men and $25.8 \mathrm{~kg} / \mathrm{m}^{2}$ in women (Reeder et al. 1992). Furthermore, $50 \%$ of all men had waist-to-hip circumference ratio (WHR) values above 0.90 , whereas $34 \%$ of women had WHR values above $0 \cdot 80$. As a high WHR indicates a relatively high accumulation of abdominal fat, it appears that a very significant proportion of the Canadian population is overweight and has increased levels of diabetogenic and atherogenic abdominal fat. Finally, $3 \%$ of men and $5 \%$ of women had BMI levels above $35 \mathrm{~kg} / \mathrm{m}^{2}$, which suggests that massive obesity is quite prevalent in Canada (Reeder et al. 1992). No major change in the prevalence of overweight and obesity has been observed in Canada since 1978 (Canada Fitness Survey, 1982; Reeder et al. 1992), suggesting that the information provided on the health hazards of obesity has had little impact so far on the body fatness of Canadians. The prevalence in Canada is similar to that in the USA (Kuczmarski, 1992). In the USA, $25.7 \%$ of the adult population (34 million) is overweight, as 15 million men have a BMI above $27.8 \mathrm{~kg} / \mathrm{m}^{2}$ and 19 million women $\left(38 \cdot 5 \%\right.$ ) have BMI values above $27 \cdot 3 \mathrm{~kg} / \mathrm{m}^{2}$ (Kuczmarski, 1992).

\section{HEALTH HAZARDS OF OBESITY}

Obesity is frequently associated with hyperlipidaemia and NIDDM (Björntorp, 1988; Kissebah \& Peiris, 1989; Després et al. 1990a), two conditions closely associated with CVD. However, as previously mentioned, the relationship between obesity per se and CVD-related mortality, although significant, is moderate (Bouchard \& Després, 1989), as some studies have not observed any association between obesity and mortality (Larsson $e t$ al. 1981; Ernsberger \& Askew, 1987). Several factors may explain this lack of strong relationship, such as the duration of follow-up (Barrett-Connor, 1985). Most importantly, it has been shown that the regional localization of adipose tissue is more closely related to the metabolic disturbances associated with CVD than obesity per se (Krotkiewski et al. 1983; Björntorp, 1984, 1988; Kissebah et al. 1985, 1989; Kissebah \& Peiris, 1989; Després et al. 1990 a; Després, 1991 a).

In the 1940s Jean Vague (1947) suggested that the topography of adipose tissue may be an important correlate of the disturbances that were generally linked to obesity. Indeed, he reported that a gynoid type of adipose tissue topography (gluteal-femoral) had trivial 
deleterious effects on the obese patient's health status, whereas abdominal visceral obesity (android or 'male' pattern of fat distribution) was more frequently associated with diabetes, gout and atherosclerosis (Vague, 1947, 1956). Thirty-five years later, Kissebah et al. (1982) were the first to provide scientific evidence of a clear relationship between body fat distribution and alterations in plasma glucose-insulin homeostasis when they reported that women with abdominal visceral obesity showed elevated glycaemic responses and were frequently glucose intolerant in response to an oral glucose challenge in comparison with women with gluteal-femoral obesity. They also indicated that hyperinsulinaemia and high plasma triacylglycerol concentrations were significant correlates of abdominal visceral obesity, and they proposed a link between regional adipose tissue accumulation and metabolic disturbances. Similar associations were reported almost simultaneously in a large cohort of men and women by Krotkiewski et al. (1983), who further confirmed that abdominal obesity is a very significant correlate of disturbances in plasma glucose, insulin and lipid levels. More recently, results from several prospective studies have confirmed that a high accumulation of abdominal adipose tissue estimated by circumferences or skinfolds was associated with an increased probability of developing CVD and with an increased risk of CVD-related mortality (Lapidus et al. 1984; Larsson et al. 1984; Stokes et al. 1985; Ducimetière et al. 1986; Donahue et al. 1987; Terry et al. 1992), although mechanisms responsible for this association remain to be clearly established.

\section{BODY FAT DISTRIBUTION, INSULIN RESISTANCE, HYPERINSULINAEMIA AND DIABETES}

Using simple anthropometric measurements of adipose tissue distribution (skinfolds, WHR), several studies have shown that hyperinsulinaemia and insulin resistance are associated with high levels of abdominal fat (Kissebah et al. 1982; Kalkhoff et al. 1983; Krotkiewski et al. 1983; Evans et al. 1984). In a large survey of 15532 obese women, Hartz et al. (1983) have shown that obese women with an excessive accumulation of abdominal visceral fat had a relative risk of developing diabetes that was 10 -fold higher than women with gluteal-femoral fat accumulation. Results from the Gothenburg prospective study have also shown that abdominal fat increases the risk of diabetes, as it was reported that fat topography could predict the development of diabetes over a 13-year follow-up period (Ohlson et al. 1985), this relationship being partly independent of obesity. These results clearly show the importance of considering body fat distribution when the risk of developing disturbances in plasma glucose-insulin homeostasis and of diabetes is assessed in obese patients. Using computed tomography, a technique that allows the accurate assessment of adipose tissue topography (particularly the quantification of visceral $v$. subcutaneous abdominal adipose tissue areas (Borkan et al. 1982; Enzi et al. 1986; Seidell et al. 1987; Ferland et al. 1989)), it has been possible to obtain a better understanding of the relationship between visceral abdominal adipose tissue accumulation and indices of plasma glucose-insulin homeostasis. Sparrow et al. (1986) reported that the amount of visceral adipose tissue measured by computed tomography was positively correlated with the concentration of plasma glucose measured $2 \mathrm{~h}$ after glucose ingestion. We have further investigated the contribution of visceral abdominal fat to the glucose intolerance and hyperinsulinaemia in obesity in a sample of 52 premenopausal women (Després et al. $1989 c$ ). Significant associations were observed between levels of visceral abdominal fat and fasting as well as postglucose insulin and glucose concentrations $(0.49 \leqslant r \leqslant 0.59, P<$ $0.001)$. Moreover, partial correlation analyses indicated that the association between visceral abdominal fat accumulation and glucose intolerance was independent of variations 
of total adiposity. We have also compared two subgroups of 10 obese women each matched for age and level of total body fat, but with either high or low levels of visceral abdominal adipose tissue. Obese women with high levels of visceral abdominal adipose tissue showed higher fasting plasma glucose, insulin and C-peptide levels, as well as higher insulin and glucose responses to an oral glucose challenge, suggesting an impaired peripheral insulin action (Després et al. 1989c). Essentially similar results were observed, in men, as we reported that visceral adipose tissue accumulation was an independent correlate of alterations in plasma glucose-insulin concentrations after oral glucose challenge (Pouliot et al. 1992). These results clearly show the greater importance of visceral adipose tissue accumulation in comparison with obesity per se regarding their respective deleterious effects on plasma glucose-insulin homeostasis. The link between adipose tissue topography and insulin resistance and NIDDM could therefore be considered as one of the mechanisms by which abdominal obesity represents a significant health hazard.

The mechanisms by which an altered body fat topography, namely an excessive accumulation of visceral abdominal fat, may be linked to insulin resistance, glucose intolerance and hyperinsulinaemia have been investigated. It has been proposed that elevated levels of visceral abdominal adipose tissue are associated with reduced metabolic clearance of insulin, due to diminished hepatic extraction of insulin (Peiris et al. 1986, $1987 \mathrm{~b}$ ), this phenomenon contributing to systemic hyperinsulinaemia. It has also been suggested that the concentrations of non-esterified fatty acids, especially in the portal circulation, may be important mediators of this association between visceral adipose tissue deposition and reduced hepatic extraction of insulin. Indeed, high non-esterified fatty acid levels are associated with reduced binding and internalization of insulin by isolated rat hepatocytes (Hennes et al 1990; Svedberg et al. 1990). A higher basal plasma non-esterified fatty acid turnover in the fasting state has also been reported in abdominal compared to peripheral obese women (Jensen et al. 1989). Furthermore, high plasma non-esterified fatty acid concentrations are associated with insulin resistance and reduced utilization of glucose in vivo (Thiébaud et al. 1982), this phenomenon being probably explained by the glucose-fatty acid cycle (Randle et al. 1963). These alterations may lead to glucose intolerance and to reduced insulin action, leading to a compensatory increase in pancreatic insulin secretion (Felber, 1992). Thus the combination of the high lipolytic activity of visceral abdominal adipose cells (Östman et al. 1979; Rebuffé-Scrive et al. 1989, 1990) and their resistance to the antilipolytic effect of insulin (Bolinder et al. 1983) could lead to an increased exposure of non-esterified fatty acids to the liver through the portal circulation, ultimately reducing hepatic insulin extraction.

\section{REGIONAL ADIPOSE TISSUE DISTRIBUTION AND PLASMA LIPOPROTEIN LEVELS}

Preferential accumulation of adipose tissue in the abdominal area has been associated with dyslipidaemia, which may increase the risk of CVD (Kalkhoff et al. 1983; Krotkiewski et al. 1983; Després et al. 1985; Haffner et al. 1987). In this regard, high levels of abdominal adipose tissue have been associated with elevated concentrations of plasma triacylglycerols (Kissebah et al. 1982; Kalkhoff et al. 1983; Krotkiewski et al. 1983; Evans et al. 1984; Després et al. 1985; Foster et al. 1987) and reduced concentrations of plasma high-density lipoprotein cholesterol (HDL-C) (Després et al. 1985; Kissebah et al. 1985; Foster et al. 1987; Haffner et al. 1987; Anderson et al. 1988). These associations, which have been shown to be largely independent of obesity (Kissebah et al. 1985; Haffner et al. 1987; Anderson et al. 1988), may also help to explain the link between the regional distribution 
(a)

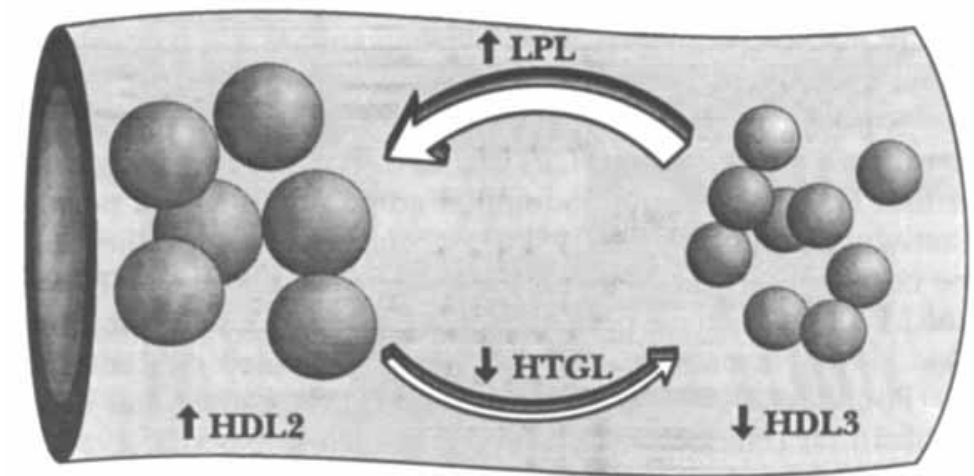

(b)

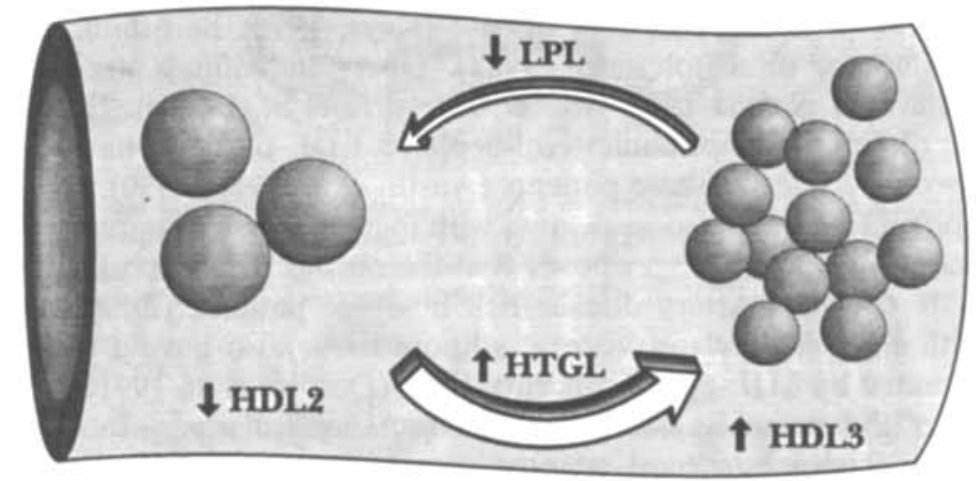

Fig. 1. Simplified model showing the importance of lipoprotein lipase (LPL) and hepatic triglyceride lipase (HTGL) activities in the regulation of plasma high-density lipoprotein (HDL) subfractions. In non-obese subjects $(a)$, relatively high LPL activity contributes to 'generate' $\mathrm{HDL}_{2}-\mathrm{C}$ particles whereas low HTGL activity is also associated with high $\mathrm{HDL}_{2}-\mathrm{C}$ levels. In abdominal visceral obese patients $(b)$, low LPL and high HTGL activities will lead to a decrease in the production of $\mathrm{HDL}_{2}$-C particles, due to a reduced catabolism of triacylglycerol rich lipoproteins and to increased degradation of $\mathrm{HDL}_{2}$ particles through increased HTGL activity.

of adipose tissue and CVD risk. Although these studies have used simple anthropometric measurements of body fat distribution, they were later confirmed by results from studies in which computed tomography was used to assess the regional distribution of body fat (Fujioka et al. 1987; Després et al. 1989 b). The level of abdominal visceral adipose tissue has been reported to be the best correlate of lipoprotein ratios (HDL-C/LDL-C, HDL $2^{-}$ $\mathrm{C} / \mathrm{HDL}_{3}-\mathrm{C}$ ) used in the estimation of CVD risk (Després et al. 1989b, 1990a). Accordingly, when we compared obese patients matched for age and total body fatness but with either low or high levels of visceral adipose tissue, lower plasma concentrations of HDL-C and $\mathrm{HDL}_{2}-\mathrm{C}$ were noted in patients with visceral obesity compared to obese subjects with low accumulation of visceral adipose tissue (Després et al. 1990a). Subjects with elevated levels of visceral abdominal adipose tissue also showed significant reductions in lipoprotein ratios predictive of CVD risk (HDL-C/LDL-C, $\mathrm{HDL}_{2}-\mathrm{C} / \mathrm{HDL}_{3}-\mathrm{C}$ and $\mathrm{HDL}-\mathrm{APO} \mathrm{A} 1 / \mathrm{LDL}-$ apo B, Després et al. 1990a). 
We have also proposed that the associations between elevated levels of visceral abdominal adipose tissue and alterations in plasma lipid and lipoprotein concentrations in abdominal obesity may be partly explained by concomitant alterations in the activities of two enzymes that hydrolyse triacylglycerols (lipoprotein lipase (LPL; EC 3.1.1.34) and hepatic triacylglycerol lipase (HTGL)) (Després et al. 1989a), as these two enzymes are significant determinants of plasma $\mathrm{HDL}$ as well as of $\mathrm{HDL}_{2}$ and $\mathrm{HDL}_{3}$ concentrations. We have reported that levels of visceral abdominal adipose tissue were positively associated with HTGL activity (Després et al. 1989a), whereas plasma postheparin LPL activity appeared to be negatively correlated with the level of total body fat (Pouliot et al. 1991). As low levels of LPL activity have been associated with reduced plasma concentrations of $\mathrm{HDL}_{2}-\mathrm{C}$ (Kekki, 1980; Eisenberg, 1983, 1984) and elevated concentrations of plasma triacylglycerols (Pouliot et al. 1991), whereas a high HTGL activity has been related to low $\mathrm{HDL}_{2}-\mathrm{C}$ concentrations (Nikkilä et al. 1987; Tikkanen \& Nikkilä, 1987), it is suggested that the reciprocal changes observed in the activity of these enzymes may be involved in the alterations in lipoprotein levels observed in abdominal visceral obesity (Fig. 1).

Measurement of LDL-C concentrations is commonly used to estimate coronary artery disease risk, and high concentrations of plasma LDL-C have been consistently associated with increased risk of coronary artery disease (Keys, 1970; Bernstein, 1985; Canadian Consensus Conference on Cholesterol, 1988). Obese individuals are not always characterized by elevated plasma LDL-C levels (Després et al. 1991 a). However, increased concentrations of small, dense, cholesterol-depleted LDL particles have been frequently observed in coronary artery disease patients (Austin et al. 1988, 1990). As elevated LDLapoprotein (apo) B levels are also associated with increased risk of coronary artery disease (Sniderman et al. 1980), we have proposed that the ratio of LDL-apo B/LDL-C could be used to estimate coronary artery disease risk in obese patients (Després et al. $1991 \mathrm{~b}$ ). Individuals with elevated levels of visceral adipose tissue also have a high LDL particle number as estimated by LDL-apo B concentrations (Després et al. 1991 b). Elevated LDLapo $B$ levels in the presence of normal LDL-cholesterol concentrations have been associated with increased visceral adipose tissue mass, insulin resistance, high triacylglycerol levels and low HDL-cholesterol concentrations (Després et al. 1991 b). This cluster of morphological and metabolic disturbances observed in visceral obesity may contribute to increase the risk of coronary artery disease (Després, 1992).

\section{ADIPOSE TISSUE DISTRIBUTION AND HYPERTENSION}

Another prevalent abnormality among obese patient is hypertension. As for the other complications, not every obese individual is hypertensive, and it has been proposed that abdominal obesity (Kalkhoff et al. 1983; Krotkiewski et al. 1983; Blair et al. 1984; Weinsier et al. 1985; Després et al. 1988) and its related insulin-resistant state (Reaven, 1988; DeFronzo \& Ferrannini, 1991) may represent better correlates of an elevated blood pressure than excess adipose tissue mass per se. It has thus been suggested that the hyperinsulinaemic insulin-resistant state associated with abdominal obesity could play an important role in the pathogenesis of hypertension (Reaven, 1988; DeFronzo \& Ferrannini, 1991). Indeed, increased insulin resistance has been observed among hypertensive patients in the presence or absence of obesity (Ferrannini et al. 1987; Reaven, 1988; Shen et al. 1988; Swislocki et al. 1989; Pollare et al. 1990). However, insulin resistance and hyperinsulinaemia are not noted in all hypertensive patients (Pollare et al. 1990), and it is obvious that additional factors are involved in the pathophysiology of arterial hypertension. Nevertheless, it is generally believed that insulin resistance may contribute to the aetiology 


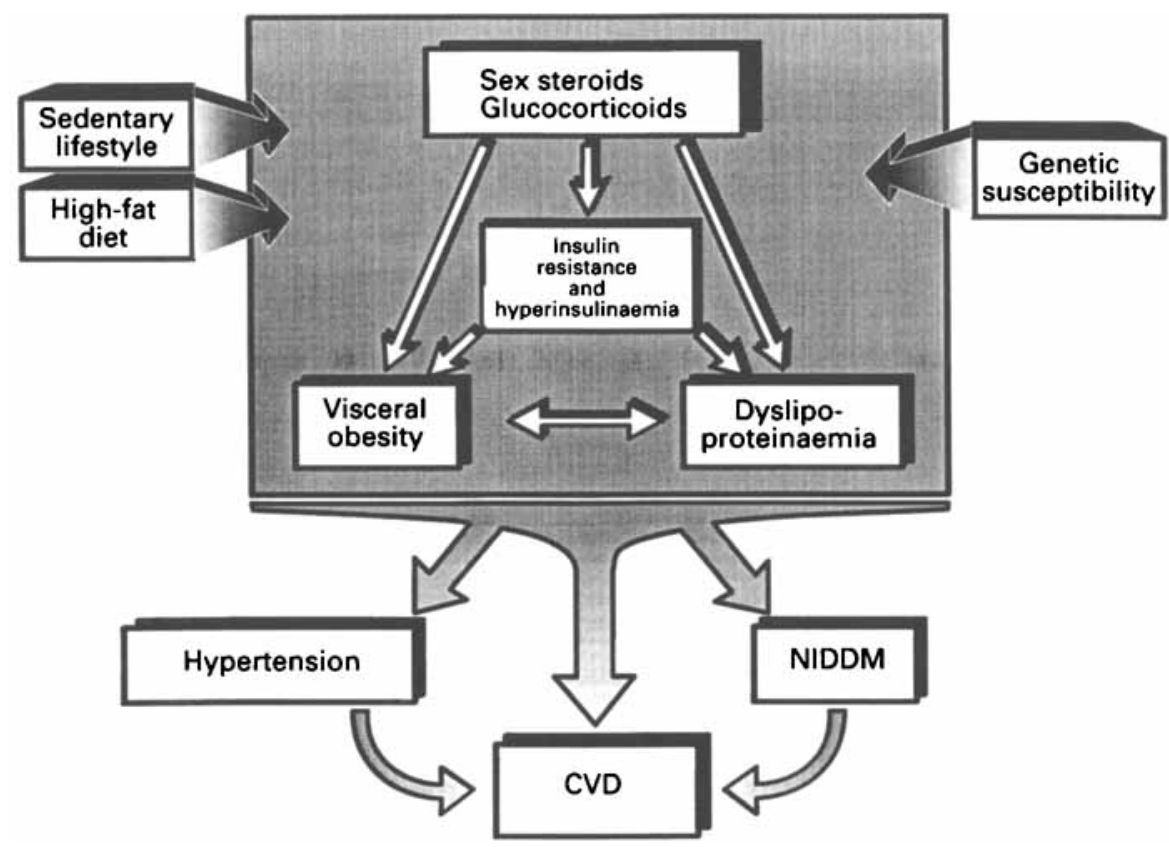

Fig. 2. Hormonal and metabolic interactions observed in visceral obesity which increase the risk of diabetes and cardiovascular disease. A sedentary lifestyle and a high fat diet may favour the development of these disturbances. Genetic variation may also exacerbate susceptibility to hypertension, non-insulindependent diabetes mellitus (NIDDM) and cardiovascular disease (CVD).

of hypertension among genetically susceptible individuals (Reaven, 1988). Thus, although the main metabolic aberrations will not always be simultaneously found, a significant number of abdominal obese patients show a cluster of disturbances that includes insulin resistance, hyperinsulinaemia, glucose intolerance, dyslipidaemia and elevated blood pressure. The simultaneous presence of these aberrations is believed to increase markedly the risk of CVD in the abdominal obese patient (Kissebah et al. 1989; Després, 1992).

\section{VISCERAL ADIPOSE TISSUE $v$. METABOLIC COMPLICATIONS: A CAUSAL RELATIONSHIP?}

The associations between increased levels of visceral adipose tissue and unfavourable alterations in the risk profile do not necessarily reflect a cause and effect relationship. Indeed, it is not established that increased accumulation of abdominal visceral adipose tissue is directly responsible for the metabolic complications associated with this condition. Several lines of evidence suggest that increased levels of abdominal visceral adipose tissue and metabolic disturbances may themselves be dependent upon the action of additional factors. In this regard, altered plasma concentrations of sex steroids have been reported in abdominal obese men and women (Evans et al. 1983; Kissebah et al. 1985; Peiris et al. $1987 a, b$; Seidell et al. 1990). As variations in plasma sex steroid concentrations are linked to carbohydrate and lipid metabolism and related to body fat distribution, it is possible that the concomitant presence of abdominal obesity, insulin resistance and dyslipidaemia may reflect the contribution of an altered sex steroid profile (Fig. 2). Furthermore, Björntorp 


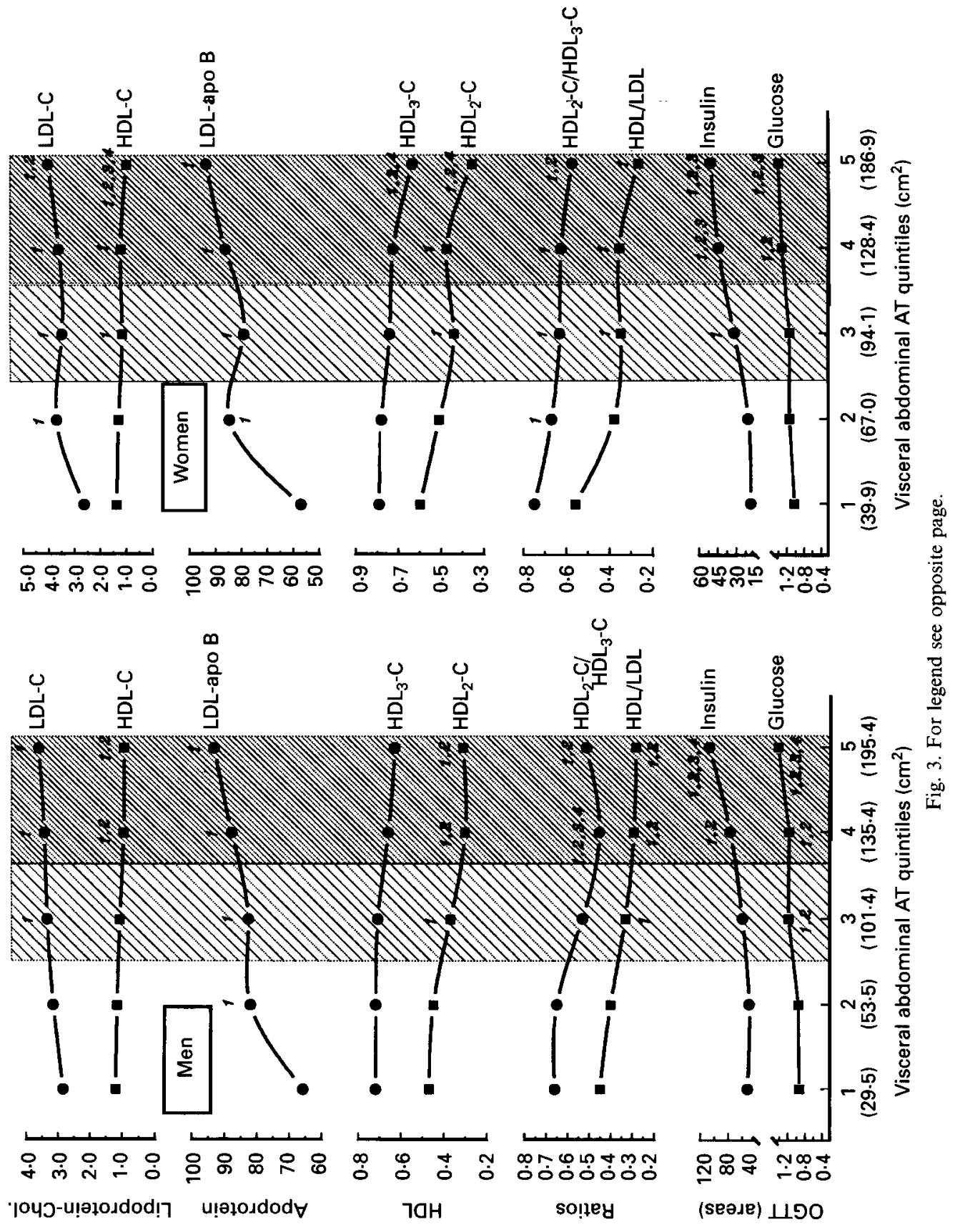


$(1991 a, b)$ has suggested that visceral obesity may, in several cases, represent a marker of a maladaptive response to stress, and that glucocorticoids may play an important role in the preferential deposition of visceral adipose tissue, as the omental adipocytes have a high concentration of glucocorticoid receptors (Rebuffé-Scrive et al. 1985). Thus, increased control of carbohydrate and lipid metabolism by glucocorticoids over insulin may provide another explanation of the relationship between visceral obesity, insulin resistance and dyslipoproteinaemias (Brindley \& Rolland, 1989).

Although it is now well established that a large accumulation of visceral adipose tissue is deleterious to health, there is no consensus on the critical level of visceral adipose tissue above which metabolic disturbances are likely to be found. To address this question, several metabolic variables predictive of diabetes and CVD risk were compared within samples of young adult men and premenopausal women (mean age 35 years) divided into quintiles on the basis of their levels of visceral adipose tissue (Fig. 3). In both men and women, an area of visceral adipose tissue above $100 \mathrm{~cm}^{2}$ was associated with moderate disturbances in the risk profile, whereas visceral adipose tissue areas greater than about $130 \mathrm{~cm}^{2}$ were associated with a further deterioration of metabolic variables predictive of NIDDM and CVD (Fig. 3). Computed tomography is a very precise tool for the assessment of visceral adipose tissue, but is expensive and not accessible to most health professionals. Waist circumference may be one of the best correlates of visceral abdominal adipose tissue and may represent a useful alternative for the assessment of the risk associated with abdominal obesity (Després et al. 1991 c). We have observed that waist circumference was a better correlate of total body fat mass and of abdominal visceral adipose tissue accumulation than WHR (Després et al. 1991 c). Variations in waist circumference were also more strongly associated with alterations in plasma lipoprotein levels than WHR (M. C. Pouliot et al. unpublished observations). These results support the concept that the simple measurement of waist circumference should be used in preference to WHR for anthropometric estimation of abdominal visceral adipose tissue deposition and related cardiovascular disease risk.

\section{CONTRIBUTION OF A LACK OF PHYSICAL ACTIVITY AND OF A HIGH FAT DIET TO THE AETIOLOGY OF OBESITY AND RELATED COMPLICATIONS}

Storage of triglycerides in the adipose tissue is dependent upon the balance between energy expenditure and energy intake. As the major factor explaining individual differences in energy expenditure is the variation in the level of physical activity (Poehlman \& Horton, 1990), a low energy expenditure will increase the probability of being in positive energy balance, for a given energy intake. However, it has been suggested that 'all calories may not be equal'. Indeed, the elegant work of Flatt (Flatt et al. 1985; Flatt, 1987a, b, 1988), followed by careful metabolic studies (Tremblay et al. 1989, 1991 b; Hill et al. 1992; Thomas et al. 1992; Tremblay, 1992) suggests that whereas raised carbohydrate intake is accompanied by an increase in carbohydrate oxidation, higher fat intake does not lead to a full compensatory rise in lipid oxidation. The result is a disturbed fat balance, which may

\footnotetext{
Fig. 3. Relationship between levels of abdominal visceral adipose tissue area (in quintiles) and variables associated with the risk of non-insulin-dependent diabetes mellitus (NIDDM) and cardiovascular disease (CVD) in samples of 115 men and 72 women respectively. This figure shows that values for visceral adipose tissue above $100 \mathrm{~cm}^{2}$ are associated with moderate but significant metabolic changes, whereas visceral adipose tissue areas greater than $135 \mathrm{~cm}^{2}$ in men and $128 \mathrm{~cm}^{2}$ in women are clearly associated with further metabolic deteriorations that may be predictive of an increased risk of NIDDM and CVD. 1, 2, 3 or $4:$ significantly different from quintiles $1,2,3$ and 4 respectively $(P<0.05)$.
} 
be an important correlate of body fat accretion (Zurlo et al. 1990; Tremblay, 1992). Thus, it appears that fat oxidation does not acutely adjust to match a high fat intake, until body fat deposition leads to fat cell hypertrophy and increased lipolysis, which by itself stimulates fat oxidation, resulting from the increased flux of free fatty acids originating from the adipose depot (Schutz et al. 1992, who have shown that a substantial gain in body fat may be needed before a new fat balance is reached under conditions of chronic exposure to high fat intake). Thus, obesity may be 'the price to pay' for an individual to achieve fat balance with a high fat intake. If this accumulation of fat occurs in the peripheral (gluteal-femoral) depots, adverse metabolic effects are likely to be minimal, whereas those who preferentially accumulate triacylglycerols in the abdominal visceral depot will be more likely to develop insulin resistance and dyslipidaemias.

It is widely documented that a diet rich in saturated fatty acids is atherogenic and is associated with increased plasma cholesterol and LDL levels (Keys, 1970; AHA Nutrition committee, 1982) and with insulin resistance (Storlien et al. 1991). Furthermore, a high fat intake has been associated with a greater proportion of abdominal adipose tissue after control for levels of total body fat (George et al. 1990). Thus the combined effects of a highfat diet rich in saturated fatty acids and of a sedentary lifestyle should contribute to increased risk of abdominal obesity, insulin resistance, NIDDM and coronary artery disease.

\section{TREATMENT OF OBESITY AND RELATED COMPLICATIONS}

\section{DIET}

A reduction in caloric intake has traditionally been used for the treatment of obesity and its metabolic consequences with highly varying (and questionable) long-term success (Brownell \& Wadden, 1992). This topic has been the subject of several review articles (Wing \& Jeffrey, 1979; Bray \& Gray, 1988; Brownell \& Kramer, 1989; Goldstein, 1992) and an extensive discussion is beyond the scope of the present paper. It is now well established that diet-induced weight loss leads to significant improvements in CVD risk factors (Blackburn \& Kanders, 1987; Bray \& Gray, 1988; Carpenter \& Bodansky, 1990; Wing et al. 1990), but the permanent normalization of body weight appears to be an unrealistic goal for a significant proportion of obese patients. However, metabolic improvements resulting from weight loss are likely to be much greater than could be predicted from the magnitude of weight loss itself, and obese patients may eventually normalize their metabolic profile without achieving their ideal body weight (Tremblay et al. 1991 a). Goldstein (1992) came to the conclusion that, in a large number of studies, a small weight loss was associated with substantial improvements in the metabolic profile and in blood pressure, which may substantially reduce the risk of developing NIDDM and CVD. This observation has considerable implications for the nutritional guidance of obese patients. Since a moderate loss in body weight (e.g. $5 \mathrm{~kg}$ ) may be easier to maintain than one of, say, $20-40 \mathrm{~kg}$, there should be less focus on the monitoring of body weight during treatment, and more on the patient's metabolic profile. Indeed, a body weight at which the risk profile is close to normal is likely to represent a true 'metabolically normal' body weight that should be aimed for.

As a general rule, there is a positive correlation between the level of total body fat and that of abdominal visceral adipose tissue in both men and women (see Fig. 4). Thus, in general, a significant loss of body fat will be associated with a reduction in the amount of abdominal fat. However, there are marked individual differences in the change of fat distribution associated with weight gain or loss, this variation being to a significant extent genetically determined (Bouchard et al. 1990a). Fujioka et al. (1991) and Leenen et al. 


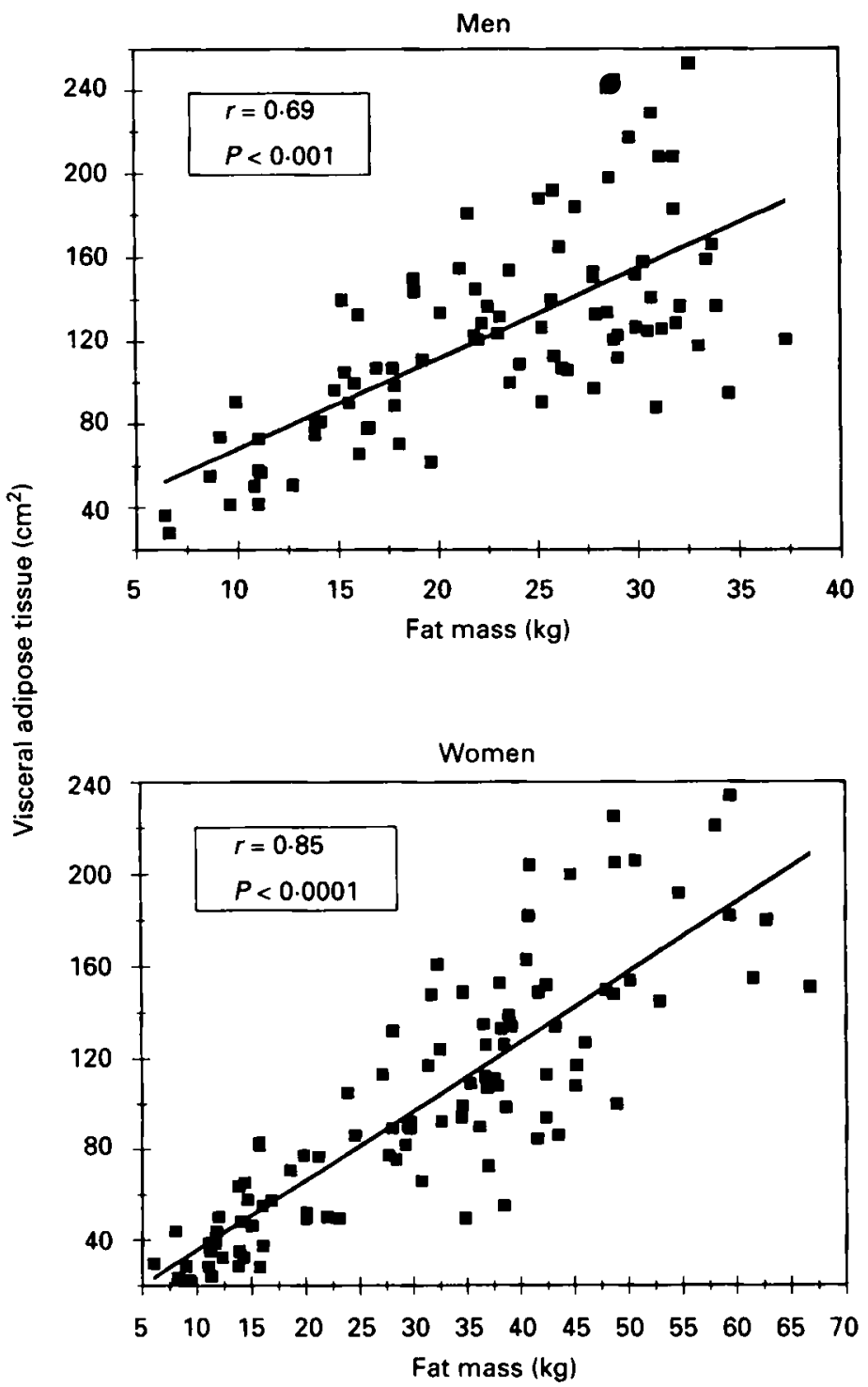

Fig. 4. Correlations between levels of total body fat mass and abdominal visceral adipose tissue areas measured by computed tomography in men and women. These relations indicate that low levels of fat mass are generally associated with low levels of abdominal visceral adipose tissue, although considerable individual variation is noted. For men $r=0.69, P<0.001$; for women $r=0.85, P<0.001$.

(1992) have reported that a high initial level of visceral adipose tissue was associated with a preferential mobilization of this depot in response to an energy deficit. Fujioka et al. (1991) have also shown that a reduction in visceral adipose tissue during weight loss was indeed associated with metabolic improvements that included improved glucose tolerance and reduced plasma insulin and lipid levels. It is therefore suggested that among patients with visceral obesity, insulin resistance and dyslipidaemia, a substantial improvement in the metabolic profile may be observed after a loss of only a few $\mathrm{kg}$ of body fat, as this may be 
related to a greater relative reduction of the amount of visceral adipose tissue than could be expected from the reduction in body weight.

\section{EXERCISE}

Theoretically, an increased daily energy expenditure by regular exercise should result in negative energy balance and eventual weight loss if it is not fully compensated by increased energy intake or reduction in the level of physical activity between exercise sessions. In general, a negative association is observed between level of physical activity, including exercise, and the level of body fat (Bouchard et al. 1993). However, studies on exercise and its effect on body fatness have generally indicated that the net energy deficit that can be produced by exercise is small, and not likely to induce major changes in body weight and adipose mass (Bouchard et al. 1993; Després, 1993). Thus an exercise programme designed for weight loss should aim at a considerable increase in energy expenditure, whereas the minimal prescription recommended to improve cardiorespiratory fitness (American College of Sports Medicine, 1990) is unlikely to induce major changes in body composition. Indeed, 3 sessions/week of endurance exercise $\left(\sim 75 \% \dot{V}_{\mathrm{O}_{2, \max }}\right)$ for about $20-30 \mathrm{~min} / \mathrm{session}$ will normally induce a net energy expenditure which will be easily compensated for by increased food intake or more sedentary habits between training bouts (Després, 1993). It has therefore been concluded that faster rates of weight loss can be achieved by hypocaloric diets than by exercise (Epstein \& Wing, 1980; Wilmore, 1983), although the latter approach is associated with a better preservation of fat-free mass than diet-induced weight loss (Després, 1993). Despite the fact that the overall effects of exercise on body composition are generally not extreme, the metabolic effects of endurance exercise training are substantial. Exercise training can favourably modify plasma lipoprotein lipid concentrations (Alterkruse \& Wilmore, 1973; Lopez-S. et al. 1974; Peltonen et al. 1981; Wood et al. 1988), improve insulin sensitivity and reduce plasma insulin concentrations (Björntorp, 1981; Koivisto et al. 1986) as well as reduce blood pressure (Krotkiewski et al. 1979; Seals \& Hagberg, 1984). Exercise has therefore been recommended for the treatment of obesity and its related metabolic complications (Bray, 1988). However, not all studies agree on this point, and several factors may explain the discrepant results reported.

One aspect that must be considered is the net increase in energy expenditure achieved and the magnitude of weight loss. Indeed, it has been suggested that the net increase in energy expenditure may represent the factor most responsible for the favourable changes in lipoprotein lipid levels and insulin sensitivity produced by endurance training ( $\mathrm{J}$.-P. Després \& B. Lamarche, unpublished observations). Williams et al. (1982) have shown that increases in HDL-C levels following a one-year endurance training programme were significantly associated with the reported miles run $(r=0.48, P<0.001)$, which provided an estimate of the training volume and of the training-related energy expenditure, whereas the correlation between increase in HDL-C and changes in $\dot{V}_{\mathrm{O}_{2}, \max }(r=0.28)$ and changes in treadmill duration $(r=0.29)$ were much weaker (Williams et al. 1982). These results suggested the importance of increasing energy expenditure (as distinct from cardiorespiratory fitness) as an approach to improving the metabolic profile through exercise training. It had been generally believed that an increase in cardiorespiratory fitness (as assessed by the measurement of $\dot{V}_{\mathrm{O}_{2} \text {. max }}$ ) was one of the requirements to alter CVD risk factors significantly through exercise training (American College of Sports Medicine, 1990). However, the minimal exercise prescription necessary to induce such changes in cardiorespiratory fitness (20-30 min endurance exercise, thrice a week) will produce marginal increases in total daily energy expenditure, and the effects on body fatness and on 
the CVD risk profile are likely to be rather small. In this regard, we have proposed the concept of 'metabolic fitness' (Després et $a l$. $1991 \mathrm{~b}$ ), which may be defined as the state of a set of metabolic variables relevant to CVD risk (plasma insulin levels, glucose tolerance, insulin sensitivity, plasma lipoprotein levels) that can be modified by exercise training. We believe that a substantial increase in daily energy expenditure, such as can be produced by a daily $45.60 \mathrm{~min}$ brisk walk, is likely to improve the metabolic condition of the overweight patient, without necessarily having any spectacular effects on cardiorespiratory fitness (Després et al. 1990 b). The American College of Sports Medicine has also recognized that the quantity and quality of exercise needed to obtain health-related benefits (metabolic fitness) may differ from what is recommended to improve cardiorespiratory fitness (American College of Sports Medicine, 1990).

The initial risk profile may also partly explain the apparently equivocal effects of exercise on body weight and CVD risk factors (Haskell, 1986; Wood \& Stefanick, 1988; Raz et al. $1988 \mathrm{~b}$ ). Indeed, individuals with initially high levels of adiposity, insulin resistance and with a deteriorated lipid lipoprotein profile are likely to benefit more from exercise training than sedentary obese subjects with a favourable metabolic profile. It has also been suggested that individuals with hyperplastic obesity (elevated number of fat cells) tend to show a reduced response to exercise training in terms of fat loss, as opposed to subjects with hypertrophic obesity, who generally lose fat more easily and at a faster rate (Bray, 1988). Finally, one has to keep in mind that many training studies were not designed to induce body weight loss, but rather to investigate the metabolic effects of exercise, and the caloric intake was not controlled in several of these studies (Farrell \& Barboriak, 1980; Nye et al. 1981; Rogers et al. 1987; Raz et al. 1988a). This may also have contributed to the divergent results obtained.

In an attempt to address this issue, the effects of daily low-intensity prolonged exercise over a 100-day period were examined in a sample of overweight men (Bouchard et al. 1990 b; Després et al. 1990 b; Tremblay et al. 1990). Subjects' energy intake was rigorously maintained at the baseline level determined when subjects were sedentary with a stable body weight. Furthermore, men were kept in a metabolic ward during the experiment, in order to ensure that potential changes observed would result solely from the energy deficit resulting from exercise. Although the low-intensity endurance exercise training programme induced a $353 \mathrm{MJ}$ energy deficit, it had no significant effect on $\dot{V}_{\mathrm{O}_{2} \cdot \max }$ (Bouchard et al. $1990 \mathrm{~b}$; Després et al. $1990 \mathrm{~b}$; Tremblay et al. 1990). Body fat loss was, however, considerable $(6.6 \mathrm{~kg})$, and substantial changes in lipid (Després et al. 1990 b) and carbohydrate (Tremblay et al. 1990) metabolism were observed (Fig. 5), suggesting improved plasma lipid transport and increased insulin sensitivity. This apparent dissociation between cardiorespiratory and metabolic components of fitness is also supported by the well-controlled randomized study of Wood et al. (1988), who observed that when diet-induced reduction in body weight was comparable to weight loss produced by exercise training, essentially similar increases in plasma HDL-cholesterol were noted after a one-year protocol. Their results also suggested that body fat loss, whether exercise or diet induced, is largely responsible for the favourable changes in plasma HDL-C concentrations, as negative correlations between changes in HDL-C levels and changes in body weight were observed in both dieters and exercisers $(-0.54 \leqslant r \leqslant-0.37, P<0.05)$. Thus, if weight loss is a significant correlate of metabolic changes produced by exercise training, the production of a large energy expenditure should become the main objective of any programme aiming at reducing CVD risk by exercise.

As significant associations between abdominal, especially visceral, adipose tissue accumulation and metabolic complications have been documented (Sparrow et al. 1986; Fujioka et al. 1987; Després et al. $1989 b, c)$, reductions in the level of visceral adipose tissue 


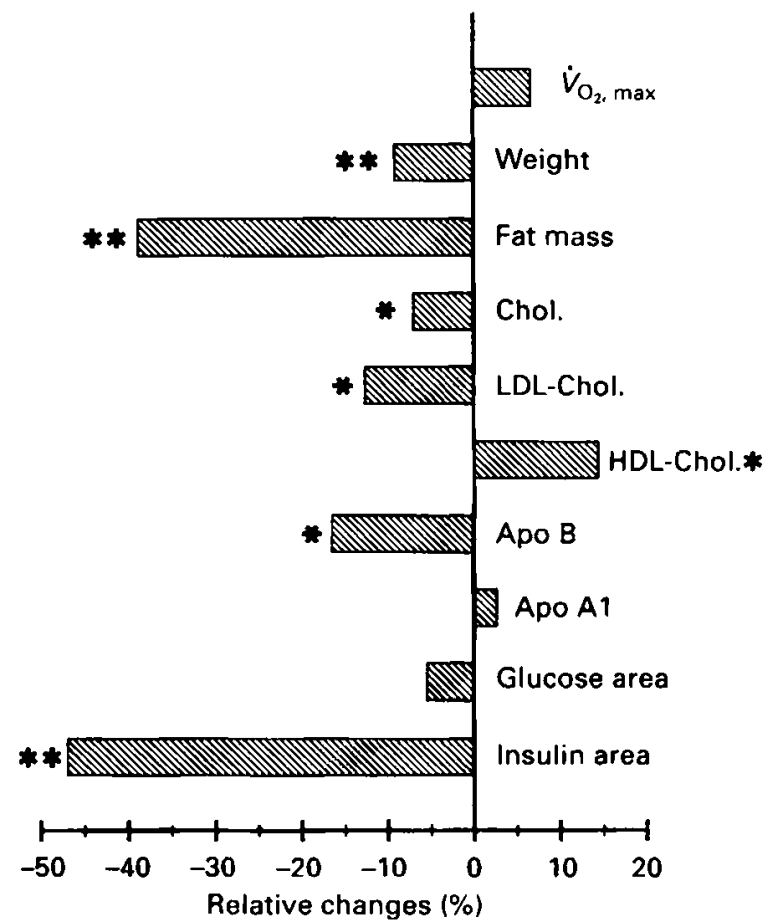

Fig. 5. Relative changes (*, $P<0.05, * *, P<0.01$ ) in glucose and insulin responses to an oral glucose challenge as well as in plasma lipoprotein levels following a 100-day low-intensity endurance exercise training programme that produced a daily $4.2 \mathrm{MJ}$ energy deficit but no significant change in maximal aerobic power $\left(\dot{V}_{\mathrm{O}_{2} \text { max }}\right)$ in a sample of overweight men. Adapted from Bouchard et al. 1990b; Tremblay et al. 1990; Despres el al. 1990b. Chol., cholesterol; HDL, high density, LDL, low density lipoprotein.

through training may thus represent one of the mechanisms by which endurance exercise training can favourably alter insulin sensitivity and lipid transport. To investigate this possibility further, we have studied the morphological as well as the metabolic responses to endurance training in a group of obese premenopausal women who were trained at about $55 \%$ of their $\dot{V}_{\mathrm{O}_{2}, \mathrm{max}}, 4-5$ sessions of $90 \mathrm{~min}$ per week, for a period of 14 months (Després et al. 1991 a). The training programme induced significant reductions in plasma cholesterol, LDL-C and apo $\mathbf{B}$ levels and in the insulin response to an oral glucose challenge, and a significant increase in plasma $\mathrm{HDL}_{2}-\mathrm{C}$ levels. Metabolic responses were not correlated with changes in $\dot{V}_{\mathrm{O}_{2} \text {. max }}$ but were significantly associated with reductions in the level of total body fat and with the loss of abdominal visceral fat. These results suggest that losses in total body fat and in the level of abdominal adipose tissue are more important correlates of changes induced by endurance exercise training in carbohydrate and lipid metabolism than in cardiorespiratory fitness.

Furthermore, exercise training per se seems to have beneficial effects on the CVD risk profile, irrespective of changes in body composition. Indeed, favourable changes in lipoprotein profile (Nye et al. 1981; Lampman et al. 1985; Raz et al. 1988b; Després, 1991 b; Lamarche et al. 1992), in insulin sensitivity (Björntorp et al. 1970; Krotkiewski \& Björntorp, 1986; Oshida et al. 1989; Lamarche et al. 1992) and in blood pressure (Krotkiewski et al. 1979) have been reported, and these improvements were observed without any reduction in body weight or fat. The relation between body fat loss and metabolic improvements following a 6-month endurance exercise training programme was 


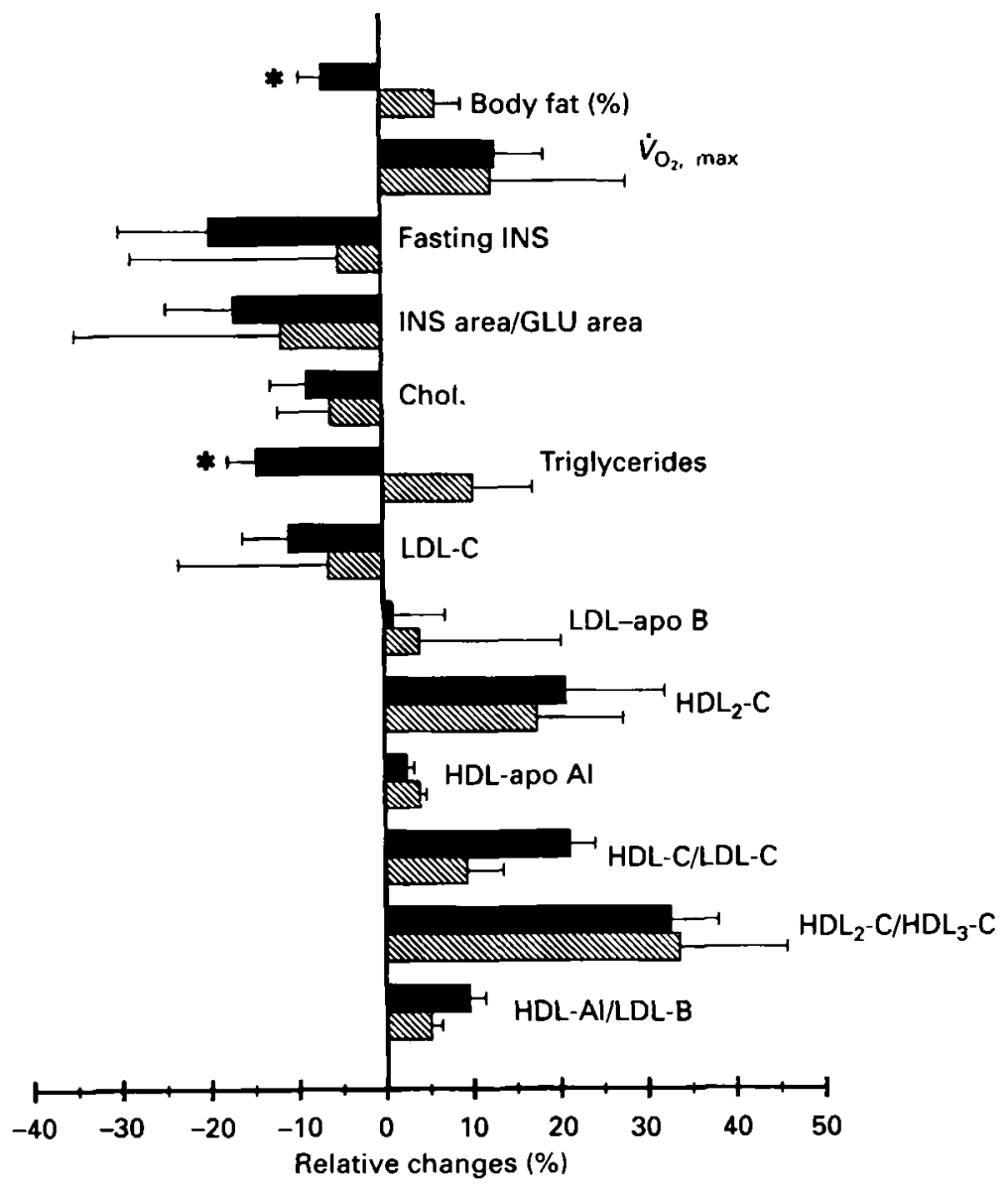

Fig. 6. Relative changes reported in a sample of 31 obese women who took part in a 6-month endurance exercise training protocol (see text for further details). All relative changes were comparable between both groups, except for changes in body fatness $(\%)$ and plasma triglyceride levels $(*, P<0.05)$. Adapted from Lamarche et al. 1992. Chol., cholesterol; GLU, glucose; HDL, high density lipoprotein; INS, insulin. $\square$, Fat loss; $\$$, fat gain.

further investigated in a sample of 31 obese premenopausal women (Lamarche et al. 1992). Twenty of these women showed a mean body fat mass reduction of $2.6 \mathrm{~kg}$ in response to training, whereas 11 gained an average of $2.8 \mathrm{~kg}$ in body fat mass despite the strenuous training programme, which included 5 sessions of 90 min endurance exercise $(55 \%$ of $\dot{V}_{\mathrm{o}_{2}, \text { max }}$ ) per week. Initial levels of adipose tissue were comparable between the two groups, and the caloric intake reported by participants appeared to remain constant throughout the study in both groups. We have compared the metabolic response to training in both groups and noted that the endurance training programme appeared to compensate for the 'deleterious' effects of an increase in fat mass among the 'fat gainers', since these women showed improvements in carbohydrate and lipoprotein lipid metabolism that were essentially similar to those observed among women who lost body fat (Fig. 6; Lamarche et al. 1992). In both groups, the improvement in cardiorespiratory fitness $\left(\dot{V}_{\mathrm{O}_{2}, \max }\right)$ was not related to changes in plasma insulin levels or in the lipoprotein profile. One may suggest in the light of these results that lack of exercise may be more important than excess body 
weight as a cause of metabolic abnormalities associated with obesity, since an increase in physical activity may almost normalize the risk profile of the obese patients in the absence of major weight loss. However, from the result of Wood et al. (1988), who emphasized the importance of the concomitant loss of body weight in explaining the metabolic response to exercise training, it would appear more appropriate to suggest that although sedentariness is a major correlate of the metabolic aberrations associated with obesity, the excess of adipose tissue mass also contributes significantly to the pathophysiology of the disturbances observed.

Many studies have not reported significant changes in LDL-C levels following exercise training (Leon et al. 1979; Wood et al. 1983; Raz et al. 1988 b; Weintraub et al. 1989) -a variable frequently used to estimate CVD risk. However, such a lack of change in total LDL-C levels following training may mask favourable changes in LDL composition and in the concentrations of LDL subfractions (Lindgren et al. 1969; Krauss \& Burke, 1982). Indeed, Williams et al. (1990) have shown in a sample of 150 moderately overweight men who exercised for one year (with or without diet), 25-50 min/session, 3-5 times/week, that regular exercise combined with weight loss increased $\mathrm{LDL}$ peak flotation rate, as well as LDL peak particle diameter, and decreased small LDL plasma mass concentrations despite no change in mean plasma LDL-C concentration. It was therefore suggested that LDL-C measurements might be insensitive to changes in LDL distribution, since exercise training may induce simultaneous changes in small LDL, large LDL and intermediate density lipoprotein cholesterol levels.

\section{THERAPEUTIC IMPLICATIONS}

We believe that the concepts discussed in this article have several therapeutic implications. First, it is now well recognized that the hazards of obesity vary greatly, even among obese patients with similar levels of total body fat. In this regard, the regional distribution of adipose tissue (particularly the deposition of visceral adipose tissue in the abdominal area) is an important factor to consider in the nutritional and clinical assessment of the obese patient. As the waist circumference is a significant correlate of total and visceral adipose tissue, its use is strongly recommended for estimating the risk associated with obesity and for monitoring the response to treatment. Secondly, as substantial metabolic improvements may be observed with moderate loss of body fat induced by diet or exercise (Fig. 7), the clinical and nutritional supervision of the patient should focus on monitoring changes in risk factors rather than on the normalization of body fatness, the latter objective being an unrealistic goal for many overweight patients. Furthermore, among patients with initially high levels of visceral adipose tissue, a small loss of total body fat may be associated with a considerable reduction of the visceral adipose tissue mass which, in turn, may be related to a substantial concomitant improvement in health. Finally, exercise has been shown to favour a preferential mobilization of abdominal visceral fat, which may itself contribute to further metabolic improvements. However, the beneficial effects of exercise on the obese patient's risk profile appear to be mediated by two partly independent factors, the first being losses of total and visceral fat associated with exercise, and the second reflecting the independent effect of increased energy expenditure on insulin sensitivity and plasma lipid transport.

In summary, it is proposed that a low fat diet, combined with regular low intensity but prolonged exercise on an almost daily basis (such as a daily brisk walk for about 40-60 min) may represent the best way to normalize the obese patient's risk profile. Such marked improvements in health may, however, be observed without normalization of body fatness. 


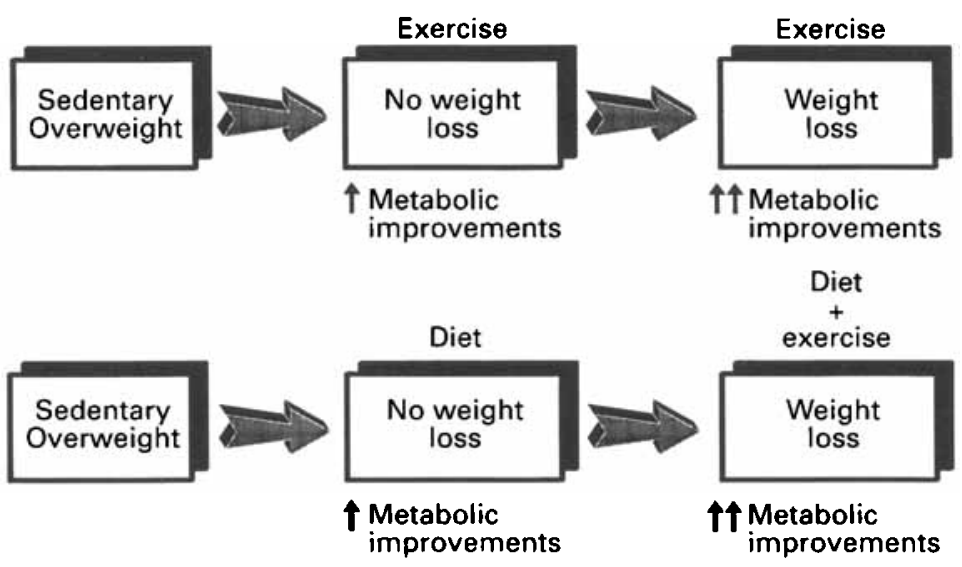

Fig. 7. Conceptual model for the effects of diet and exercise on risk factors for non-insulin-dependent diabetes mellitus and coronary heart disease. In the upper panel, it is proposed that endurance exercise may improve insulin sensitivity and plasma lipid transport in the absence of weight loss. However, further metabolic improvements will be observed when exercise training is associated with losses of total and abdominal adipose tissue. From this model, further loss of body weight produced by diet and exercise should optimize reduction in risk. In the lower panel, jt is shown that diet induced weight loss may also induce significant metabolic improvements. It is proposed that endurance exercise should lead to additional metabolic improvements.

\section{REFERENCES}

AHA Nutrition Committee (1982). Rationale of the diet-heart statement of the American Heart Association Arteriosclerosis 2. 177-191.

Altekruse, E. G. \& Wilmore, J. H. (1973). Changes in blood chemistries following a controlled exercise program. Journal of Occupational Medicine 15, $110+113$

American College of Sports Medicine (1990). Position stand: The recommended quantity and quality of exercise for developing and maintaining cariorespiratory and muscular fitness in healthy adults. Medicine and Science in Sports and Exercise 22, 265-274.

Anderson, A. J., Sobocinski, K. A., Freedman, D. S., Barboriak, J. J., Rimm, A. A. \& Gruchow, H. W. (1988). Body fat distribution, plasma lipids, and lipoproteins. Arteriosclerosis 8, 88-94.

Austin, M. A., Breslow, J. L., Hennekens, C. H., Buring, J. E., Willett, W. C. \& Krauss, R. M. (1988). Low density lipoprotein subclass patterns and risk of myocardial infarction. Journal of the American Medical Association 260, 19171921

Austin, M. A.. King, M.-C., Vranizan, K. M. \& Krauss, R. M. (1990). Atherogenic lipoprotein phenotype. A proposed genetic marker for coronary heart disease risk. Circulation 82, 495-506.

Barrett-Connor, E. L. (1985). Obesity, atherosclerosis, and coronary artery disease. Annals of Internal Medicine $103,10101019$.

Bernstein, M. J. (1985). Lowering blood cholesterol to prevent heart disease. Journal of the American Medical Association 253, 2080-2086.

Björntorp, P. (1981). Effects of exercise on plasma insulin. International Journal of Sports Medicine 2, 125-129.

Björntorp, P. (1984). Hazards in subgroups of human obesity (editorial). European Journal of Clinical Investigation 14, 239 241.

Björntorp, P. (1988). Abdominal obesity and the development of non-insulin dependent diabetes mellitus. Diabetes/Metabolism Reviews 4, 615622.

Björntorp, P. (1991 $a$ ). Visceral fat accumulation : the missing link between psychosocial factors and cardiovascular disease? Journal of Internal Medicine 230, 195-201.

Björntorp, P. (1991 b). Metabolic implications of body fat distribution. Diabetes Care 14, 1132-1143.

Björntorp, P.. De Jounge. K.. Sjöström, L. \& Sullivan, L. (1970). The effect of physical training on insulin production in obesity. Metabolism 19, 631-638.

Blackburn, G. L. \& Kanders, B. S. (1987). Medical evaluation and treatment of the obese patient with cardiovascular disease. American Journal of Cardiology 60 (12), 55G-58G.

Blair, D., Habicht, J. P., Sims, E. A. H., Sylwester, D. \& Abraham, S. (1984). Evidence for an increased risk for hypertension with centrally located body fat and the effect of race and sex on this risk. American Journal of Epidemiology 119, 526-540. 
Bolinder, J., Kager, L., Östman, J. \& Arner, P. (1983). Differences at the receptor and postreceptor levels between human omental and subcutaneous adipose tissue in the action of insulin on lipolysis. Diabetes 32, 117-123.

Borkan, G. A., Gerzof, S. G., Robbins, A. H., Hults, D. E., Silbert, C. K. \& Silbert, J. E. (1982). Assessment of abdominal fat content by computed tomography. American Journal of Clinical Nutrition 36, $172-177$.

Bouchard, C. \& Després, J. P. (1989). Variation in fat distribution with age and health implications. In Physical Activity and Aging, pp. 78-106 [H. M. Eckert and W. Spirduso, editors]. American Academy of Physical Education.

Bouchard, C., Després, J. P. \& Tremblay, A. (1993). Exercise and obesity. Obesity Research 1, 40-54.

Bouchard, C. Tremblay, A., Després, J.-P., Nadeau, A., Lupien, P. J., Thériault, G., Dussault, J., Moorjani, S., Pineault, S. \& Fournier, G. $(1990 a)$. The response to long-term overfeeding in identical twins. New England Journal of Medicine 322, 1477-1482.

Bouchard, C.. Tremblay, A., Nadeau, A., Dussault, J., Després, J.-P., Thériault, G., Lupien, P. J., Serresse, O., Boulay, M. R. \& Fournier, G. (1990b). Long-term excrcise training with constant energy intake. 1. Effect on body composition and selected metabolic variables. International Journal of Obesity 14, 57-73.

Bray, G. A. (1985). Complications of obesity. Annals of Internal Medicine 103, 1052-1062.

Bray, G. A. (1988). Exercise and obesity. In Exercise, Fitness and Health: a consensus of current knowledge, pp. 497510 [C. Bouchard, R. J. Shephard, T. Stephens, J. R. Sutton and B. D. McPherson, editors]. Champaign, IL: Human Kinetics Publishers.

Bray, G. A. \& Gray, D. S. (1988). Treatment of obesity: an overview. Diabetes/Metabolism Revien:s 4, $653-679$.

Brindley, D. N. \& Rolland, Y. (1989). Possible connections between stress, diabetes, obesity, hypertension and altered lipoprotein metabolism that may result in atherosclerosis. Clinical Science 77, 453-461.

Brownell, K. D. \& Kramer, F. M. (1989). Behavioural management of obesity. Medical Clinics of North America 73, 185201.

Brownell, K. D. \& Wadden, T. A. (1992). Etiology and treatment of obesity. Understanding a serious, prevalent and refractory disorder. Journal of Consulting and Clinical Psychology 60, 505517

Canada Fitness Survey (1982). Canada's Fimess: preliminary findings of the 1981 survey.

Canadian Consensus Conference on Cholesterol (1988). Final report. Canadian Medical Association Jourmal 139 (11, suppl.). 1-8.

Carpenter, M. A. \& Bodansky, H. J. (1990). Drug treatment of obesity in type II diabetes mellitus. Diabetic Medicine 7, 99104.

Danforth, E. (1985). Diet and obesity. American Journal of Clinical Nutrition 41. 1132-1145.

DeFronzo, R. A. \& Ferrannini, E. (1991). Insulin resistance: a multifaceted syndrome responsible for NIDDM, obesity, hypertension, dyslipidemia, and atherosclerotic cardiovascular disease. Diabetes Care 14, 173 - 194.

Després, J.-P. (1991 a). Obesity and lipid metabolism: relevance of body fat distribution. Current Opinion in Lipidology' 2, 5-15.

Després, J.-P. (1991 b). Obesity, regional adipose tissue distribution and metabolism: effect of exercise. In Obesity: dietary factors and control, pp. 251-259 [D. R. Romsos, J. Himms-Hagen and M. Suzuki, editors]. Tokyo: Japan Scientific Societies Press.

Després, J.-P. (1992). Clustering of risk factors for cardiovascular disease in abdominal obesity. Canadian Lipidology Review 2. 15-23.

Després, J.-P. (1993). Physical activity and adipose tissuc. In Physical Activity, Fitness \& Health [C. Bouchard, R. J. Shephard and T. Stephens, editors]. Champaign, IL: Human Kinetics Publishers. (In the Press).

Després, J.-P., Allard, C., Tremblay, A., Talbot, J. \& Bouchard, C. (1985). Evidence for a regional component of body fatness in the association with serum lipids in men and women. Metabolism 34, 967973.

Després, J.-P., Ferland, M., Moorjani, S., Nadeau, A., Tremblay, A., Lupien, P. J., Thériault, G. \& Bouchard, C. $(1989 a)$. Role of hepatic-triglyceride lipase activity in the association between intra-abdominal fat and plasma HDL cholesterol in obese women. Arteriosclerosis 9, 485-492.

Després, J.-P., Moorjani, S., Ferland, M., Tremblay, A., Lupien, P. J., Nadeau, A., Pinault, S., Thériault. G. \& Bouchard, C. $(1989 \mathrm{~b})$. Adipose tissue distribution and plasma lipoprotein levels in obese women: importance of intra-abdominal fat. Arteriosclerosis 9, 203-210.

Després, J.-P., Moorjani, S., Lupien, P. J., Tremblay, A., Nadeau, A. \& Bouchard, C. (1990a). Regional distribution of body fat, plasma lipoproteins, and cardiovascular disease. Arteriosclerosis 10, 497511.

Després, J.-P., Nadeau, A., Tremblay, A., Ferland, M. \& Lupien, P. J. (1989c). Role of deep abdominal fat in the association between regional adipose tissue distribution and glucose tolerance in obese women. Diabetes 38 , 304-309.

Després, J.-P., Pouliot, M.-C., Moorjani, S., Nadeau, A., Tremblay, A., Lupien, P. J., Thériault, G. \& Bouchard, C. $(1991 \mathrm{a})$. Loss of abdominal fat and metabolic response to exercise training in obese women. American Journal of Physiology 261, E159 E167.

Després, J.-P.. Pouliot, M. C., Prud'homme, D., Moorjani, S. Lupien, P. J., Nadeau, A., Tremblay, A. \& Bouchard, C. $(1991 b)$. Abdominal obesity, hyperinsulinaemia and related hypertriglyceridaemia are important correlates of LDL composition in men. International Journal of Obesity 15 (suppl. 1), Abstract O37.

Després, J.-P., Prud'homme, D., Pouliot, M.-C.. Tremblay. A. \& Bouchard, C. (1991 c). Estimation of deep abdominal adipose-tissue accumulation from simple anthropometric measurements in men. American Journal of Clinical Nutrition 54, 471-477. 
Després, J.-P., Tremblay, A., Moorjani, S., Lupien, P. J., Thériault, G., Nadeau, A. \& Bouchard, C. (1990 b). Long-term excrcise training with constant energy intake. 3. Effects on plasma lipoprotein levels. International Journal of Obesity 14, 85-94.

Després, J.-P., Tremblay, A., Thériault, G., Pérusse, L., Leblanc, C. \& Bouchard, C. (1988). Relationships between body fatness, adipose tissue distribution and blood pressure in men and women. Journal of Clinical Epidemiology 41, 889-897.

Donahue, R. P., Abbott, R. D., Bloom, E., Reed, D. M. \& Yano, K. (1987). Central obesity and coronary heart disease in men. Lancet $\mathrm{i}, 821-824$.

Ducimetière, P., Richard, J. \& Cambien, F. (1986). The pattern of subcutaneous fat distribution in middle-aged men and the risk of coronary heart disease. The Paris prospective study. International Journal of Obesity 10. 299-240.

Eisenberg. S. (1983). Lipoproteins and lipoprotein metabolism. A dynamic evaluation of the plasma fat transport system. Klinische Wochenschrift 61, 119-132.

Eisenberg, S. (1984). High density lipoprotein metabolism. Journal of Lipid Research 25, 1017-1058.

Enzi, G., Gasparo, M.. Biondetti, P. R., Fiore, D., Semisa, M. \& Zurlo, F. (1986). Subcutaneous and visceral fat distribution according to sex, age, and overweight, evaluated by computed tomography. American Journal of Clinical Nutrition 44, 739746.

Epstein, L. H. \& Wing, R. R. (1980). Aerobic exercise and weight. Additive Behaviors 5, 371-388.

Ernsberger, P. \& Askew, P. (1987). Health implications of obesity: an alternative view. Journal of Obesity and Weight Regulation 6, 58137.

Evans, D. J., Hoffmann, R. G., Kalkhoff, R. K.\& Kissebah, A. H. (1983). Relationship of androgenic activity to body fat topography, fat cell morphology, and metabolic aberrations in premenopausal women. Journal of Clinical Endocrinology and Metabolism 57, 304-310.

Evans, D. J., Hoffmann. R. G., Kalkhoff, R. K. \& Kissebah, A. H. (1984). Relationship of body fat topography to insulin sensitivity and metabolic profiles in premenopausal women. Metabolism 33, 68-75.

Farrell, P. A. \& Barboriak, J. (1980). The time course of alterations in plasma lipid and lipoprotein concentrations during eight weeks of endurance training. Atherosclerosis 37, 231-238.

Felber, J. P. (1992). From obesity to diabetes. Pathophysiological considerations. International Journal of Obesity 16, 937-952.

Ferland, M., Després, J.-P.. Tremblay, A., Pinault, S., Nadeau, A., Moorjani, S., Lupien, P. J.. Thériault, G. \& Bouchard, C. (1989). Assessment of adipose tissue distribution by computed axial tomography in obese women: association with body density and anthropometric measurements. British Journal of Nutrition 61, $139-148$.

Ferrannini, E., Buzzigoli, G., Bonadonna, R., Giorico, M. A., Oleggini, M., Graziadei, L., Pedrinelli, R., Brandi, L. \& Bevilacqua, S. (1987). Insulin resistance in essential hypertension. New England Journal of Medicine 317, $350-357$.

Flatt, J. P. (1987a). The difference in the storage capacities for carbohydrate and for fat, and its implications in the regulation of body weight. Annals of the New York Academy of Sciences 499, 104123.

Flatt, J. P. (1987b). Dietary fat, carbohydrate balance, and weight maintenance: effects of exercise. American Journal of Clinical Nutrition 45, 296-306.

Flatt, J. P. (1988). Importance of nutrient balance in body weight regulation. Diabetes/Metabolism Reviews 4 , $571-581$.

Flatt, J. P., Ravussin, E., Acheson, K. J. \& Jéquier, E. (1985). Effects of dietary fat on postprandial substrate oxidation and on carbohydrate and fat balances. Journal of Clinical Investigation 76, 1019-1024.

Foster, C. J., Weinsier, R. L., Birch, R., Norris, D. J., Bernstein, R. S., Wang, J., Pierson, R. N. \& Van Itallie, T. B. (1987). Obesity and serum lipids: an evaluation of the relative contribution of body fat and fat distribution to lipid levels. International Journal of Obesity 11, 151161.

Fujioka, S., Matsuzawa, Y., Tokunaga, K., Kano, Y., Kobatake, T. \& Tarui, S. (1991). Treatment of visceral fat obesity. International Journal of Obesity 15 (Suppl. 2), 59-65.

Fujioka, S., Matsuzawa, Y., Tokunaga, K. \& Tarui, S. (1987). Contribution of intra-abdominal fat accumulation to the impairment of glucose and lipid metabolism in human obesity. Metabolism 36, 54-59.

George, V., Tremblay, A., Després, J.-P., Leblanc, C. \& Bouchard, C. (1990). Effect of dietary fat content on total and regional adiposity in men and women. International Journal of Obesity 14, 1085-1094.

Goldstein, D. J. (1992). Beneficial health effects of modest weight loss. International Journal of Obesity 16, 397415.

Haffner, S. M., Stern, M. P., Hazuda, H. P., Pugh, J. \& Patterson, J. K. (1987). Do upper-body and centralized adiposity measure different aspects of regional body-fat distribution? Relationship to non-insulin dependent diabetes mellitus, lipids, and lipoproteins. Diabetes 36, 43-51.

Harrison, G. G. (1985). Height-weight tables. Annals of Internal Medicine 103, 989994.

Hartz, A. H., Rupley, D. C., Kalkhoff, R. D. \& Rimm, A. A. (1983). Relationship of obesity to diabetes: influence of obesity and body fat distribution. Preventive Medicine 12, 351357.

Haskell, W. L. (1986). The influence of exercise training on plasma lipids and lipoproteins in health and disease. Acta Medica Scandinavica Suppl. 711, 25-37.

Hennes, M. M. I., Shrago, E. \& Kissebah, A. H. (1990). Receptor and postreceptor effects of free fatty acids (FFA) on hepatocyte insulin dynamics. International Journal of Obesity 14, 831-841. 
Hill, J. O., Lin, D., Yakubu, F. \& Peters, J. C. (1992). Development of dietary obesity in rats: influence of amount and composition of dietary fat. International Journal of Obesity 16, 321-333.

Hubert. H. B., Feinleib, M.. McNamara, P. M. \& Castelli, W. P. (1983). Obesity as an independent risk factor for cardiovascular disease-a 26-year follow-up of participants in the Framingham heart study. Circulation 67, 968-977.

Jensen, M. D., Haymond, M. W., Rizza, R. A., Cryer, P. E. \& Miles, J. M. (1989). Influence of body fat distribution on free fatty acid metabolism in obesity. Journal of Clinical Investigation 83. 1168-1173.

Kalkhoff, R. K.. Hartz, A. H., Rupley, D., Kissebah, A. H. \& Kelber, S. (1983). Relationship of body fat distribution to blood pressure, carbohydrate tolerance, and plasma lipids in healthy obese women. Journal of Laboratory and Clinical Medicine 102, 621-627.

Kekki, M. (1980). Lipoprotein-lipase action determining plasma high density lipoprotein cholesterol levels in adult normolipaemics. Atherosclerosis 37, 143150.

Keys, A. (1970). Coronary heart disease in seven countries. Circulation 41 (Suppl. 1), 11-1211.

Kissebah, A. H., Evans, D. J., Peiris, A. \& Wilson, C. R. (1985). Endocrine characteristics in regional obesities: role of sex steroids. In Metabolic Complications of Human Obesities, pp. 115-130 [J. Vague, P. Björntorp, B Guy-Grand, M. Rebuffé-Scrive and P. Vague, editors]. Amsterdam: Elsevier.

Kissebah, A. H., Freedman, D. S. \& Peiris, A. N. (1989). Health risks of obesity. Medical Clinics of North America 73, 111138

Kissebah, A. H. \& Peiris, A. N. (1989). Biology of regional body fat distribution: relationship to non-insulindependent diabetes mellitus. Diabetes/Metabolism Revien's 5, 83109.

Kissebah, A. H., Vydelingum, N., Murray, R., Evans, D. J., Hartz, A. J., Kalkoff, R. K. \& Adams, P. W. (1982). Relation of body fat distribution to metabolic complications of obesity. Journal of Clinical Endocrinology and Metabolism 54, 254260.

Koivisto, V. A., Yki-Järvinen, H. \& DeFronzo, R. A. (1986). Physical training and insulin sensitivity. Diabetes/Metabolism Review's 1, 445481 .

Krauss, R. M. \& Burke, D. J. (1982). Identification of multiple subclasses of plasma low density lipoproteins in normal humans. Journal of Lipid Research 23, 97104.

Krotkiewski, M. \& Björntorp. P. (1986). Muscle tissue in obesity with different distribution of adipose tissue: effects of physical training. International Journal of Obesity 10, 331341.

Krotkiewski, M., Björntorp, P., Sjöström, L. \& Smith. U. (1983). Impact of obesity on metabolism in men and women. Importance of regional adipose tissue distribution. Journal of Clinical Investigation 72, 11501162

Krotkiewski, M., Mandroukas, K., Sjöström, L., Sullivan, L., Wetterqvist, H. \& Björntorp, P. (1979). Effects of long-term physical training on body fat, metabolism. and blood pressure in obesity. Metabolism 28, $650-658$.

Kuczmarski, R. J. (1992). Prevalence of overweight and weight gain in the United States. American Journal of Clinical Nutrition 55, 495S 502S.

Lamarche, B., Després, J.-P., Pouliot, M.-C., Moorjani, S., Lupien, P. J., Thériault, G., Tremblay, A., Nadeau, A. \& Bouchard, C. (1992). Is body fat loss a determinant factor in the improvement of carbohydrate and lipid metabolism following aerobic exercise training in obese women? Metabolism 41, 1249-1256.

Lampman. R. M.. Santinga. J. T., Savage, P. J., Bassett, D. R., Hydrick, C. R., Flora, J. D. \& Block. W. D. (1985). Effect of exercise training on glucose tolerance, in vivo insulin sensitivity, lipid and lipoprotein concentrations in middle-aged men with mild hypertriglyceridemia. Metabolism 34, 205-211.

Lands, W. E. M., Hamazaki, T., Yamazaki, K., Okuyama, H., Sakai, K., Goto, Y. \& Hubbard, V. S. (1990). Changing dietary patterns. American Journal of Clinical Nutrition 51. 991993.

Lapidus, L., Bengtsson, C., Larsson, B., Pennert, K., Rybo, E. \& Sjöström, L. (1984). Distribution of adipose tissue and risk of cardiovascular disease and death: a 12 year follow up of participants in the population study of women in Gothenburg. Sweden. British Medical Journal 289, 12571261.

Larsson, B., Björntorp, P. \& Tibblin. G. (1981). The health consequences of moderate obesity. International Journal of Obesity 5, 97-116.

Larsson, B., Svärdsudd, K., Welin, L., Wilhemsen, L., Björntorp, P. \& Tibblin, G. (1984). Abdominal adipose tissue distribution, obesity, and risk of cardiovascular disease and death: 13 year follow up of participants in the study of men born in 1913. British Medical Journal 288, 1401-1404.

Leenen, R., Van der Kooy, K., Deurenberg, P., Seidell, J. C., Weststrate, J. A., Schouten, F. J. M. \& Hautvast, J. G. A. J. (1992). Visceral fat accumulation in obese subjects: relation to cnergy expenditure and response to weight loss. American Journal of Physiology 263, E913-E919.

Leon, A. S., Conrad, J., Hunninghake, D. B. \& Serfass, R. (1979). Effects of a vigorous walking program on body composition, and carbohydrate and lipid metabolism of obese young men. American Journal of Clinical Nutrition 32, 1776-1787.

Lindgren, F. T., Jensen, L. C., Wills, R. D. \& Freeman, N. K. (1969). Flotation rates, molecular weights and hydrated densities of the low-density lipoproteins. Lipids 4, 337-344.

Lopez-S., A., Vial, R., Balart, L. \& Arroyave, G. (1974). Effect of exercise and physical fitness on serum lipids and lipoproteins. Atherosclerosis $20,19$.

National Institutes of Health Consensus Development Panel on the Health Implications of Obesity (1985). Health implications of obesity. National Institutes of Health consensus development conference statement. Annals of Internal Medicine 103, 10731077. 
Nikkilä, E. A.. Taskinen, M.-R. \& Sane, T. (1987). Plasma high-density lipoprotein concentration and subfraction distribution in relation to triglyceride metabolism. American Heart Journal 113, 543-548.

Nye, E. R., Carlson, K., Kirstein, P. \& Rössner, S. (1981). Changes in high density lipoprotein subfractions and other lipoproteins induced by exercise. Clinica Chimica Acta 113, 5157.

Ohlson, L. O., Larsson, B., Svärdsudd, K., Welin, L., Eriksson, H., Wilhelmsen, L., Björntorp, P. \& Tibblin, G. (1985). The influence of body fat distribution on the incidence of diabetes mellitus: 13.5 years of follow-up of the participants in the study of men born in 1913. Diabetes 34, 1055-1058.

Oshida, Y., Yamanouchi, K., Hayamizu, S. \& Sato, Y. (1989). Long-term mild .jogging increases insulin action despite no influence on body mass index or $\dot{V}_{0_{2}, \max }$. Journal of Applied Physiology 66, 2206-2210.

Östman. J., Arner, P., Engfeldt, P. \& Kager. L. (1979). Regional differences in the control of lipolysis in human adipose tissue. Metabolism 28, 11981205.

Peiris, A. N., Mueller, R. A., Smith, G. A., Struve, M. F. \& Kissebah, A. H. (1986). Splanchnic insulin metabolism in obesity: Infuence of body fat distribution. Journal of Clinical Investigation 78, 16481657.

Peiris, A. N., Mueller, R. A., Struve, M. F., Smith, G. A. \& Kissebah, A. H. (1987a). Relationship of androgenic activity to splanchnic insulin metabolism and peripheral glucose utilization in premenopausal women. Journal of Clinical Endocrinology and Metabolism 64, 162-169.

Peiris, A. N., Struve, M. F. \& Kissebah, A. H. (1987b). Relationship of body fat distribution to the metabolic clearance of insulin in premenopausal women. International Journal of Obesity 11, 581-589.

Peltonen, P., Marniemi, J., Hietanen, E., Vuori, I. \& Ehnholm, C. (1981). Changes in serum lipids, lipoproteins, and heparin releasable lipolytic enzymes during moderate physical training in man: a longitudinal study. Metabolism 30, 518-526.

Poehlman, E. T. \& Horton, E. S. (1990). Regulation of energy expenditure in aging humans. Annual Review of Nutrition 10, 255275.

Pollare, T., Lithell, H. \& Berne, C. (1990). Insulin resistance is a characteristic feature of primary hypertension independent of obesity. Metabolism 39, 167-174.

Pouliot, M.-C.. Després, J.-P., Moorjani, S., Lupien, P. J., Tremblay, A., Nadeau, A. \& Bouchard, C. (1991). Regional variation in adipose tissue lipoprotein lipase activity: association with plasma high density lipoprotein levels. European Journal of Clinical Investigation 21, 398405.

Pouliot, M.-C., Després, J.-P., Nadeau, A., Moorjani, S., Prud’homme, D., Lupien, P. J., Tremblay, A. \& Bouchard, C. (1992). Visceral obesity in men. Associations with glucose tolerance, plasma insulin, and lipoprotein levels. Diabetes 41, 826-834.

Rabkin, S. W.. Mathewson, F. A. L. \& Hsu, P.-H. (1977). Relation of body weight to development of ischemic heart disease in a cohort of young North American men after a 26-year observation period: the Manitoba study. American Journal of Cardiology 39, 452458.

Randle, P. J., Garland, P. B., Hales, C. N. \& Newsholme, E. A. (1963). The glucose fatty acid cycle: its role in insulin sensitivity and the metabolic disturbances of diabetes mellitus. Lancet i, 785.789.

Raz., I., Israeli, A., Rosenblit, H. \& Bar-On, H. (1988a). Influence of moderate exercise on glucose homeostasis and serum testosterone in young men with low HDL-cholesterol level. Diabetes Research 9, 31 . 35.

Raz, I., Rosenblit, H. \& Kark, J. P. (1988 b). Effect of moderate exercise on serum lipids in young men with low high density lipoprotein cholesterol levels. Arteriosclerosis 8, 245-251.

Reaven, G. M. (1988). Role of insulin resistance in human disease. Diabetes 37, 15951607

Rebuffé-Scrive, M., Andersson, B., Olbe, L. \& Björntorp, P. (1989). Metabolism of adipose tissue in intraabdominal depots in nonobese men and women. Metabolism 38, 453-458.

Rebuffé-Scrive, M., Andersson, B., Olbe, L. \& Björntorp, P. (1990). Metabolism of adipose tissue in intraabdominal depots in severely obese men and women. Metabolism 39, 1021-1025.

Rebuffé-Scrive, M.. Lundholm, K. \& Björntorp, P. (1985). Glucocorticoid binding to human adipose tissue. European Journal of Clinical Investigation 15, 267-271.

Reeder, B. A., Angel, A., Ledoux, M., Rabkin, S. W., Young. T. K. \& Sweet, L. E. (1992). Obesity and its relation to cardiovascular disease risk factors in Canadian adults. Canadian Medical Association Journal Special suppl., $37-47$.

Rogers, M. A., Yamamoto, C., Hagberg, J. M., Holloszy, J. O. \& Ehsani, A. A. (1987). The effect of 7 years of intense exercise training on patients with coronary artery disease. American Journal of Cardiology 10, 321.326.

Schutz, Y., Tremblay, A.. Weinsier, R. L. \& Nelson, K. M. (1992). Role of fat oxidation in the long-term stabilization of body weight in obese women. American Journal of Clinical Nutrition 55, 670-674.

Seals, D. R. \& Hagberg, J. M. (1984). The effect of exercise training on human hypertension: a review. Medical Science in Sports and Exercise 16, 207-215.

Seidell, J. C.. Björntorp, P., Sjöström, L.. Kvist, H. \& Sannerstedt, R. (1990). Visceral fat accumulation in men is positively associated with insulin, glucose, and C-peptide levels, but negatively with testosterone levels. Metabolism 39, 897-901.

Seidell, J. C., Oosterlee, A., Thijssen. M. A. O., Burema, J., Deurenberg, P., Hautvast, J. G. A. J. \& Ruijs, J. H. J. (1987). Assessment of intra-abdominal and subcutaneous abdominal fat: relation between anthropometry and computed tomography. American Journal of Clinical Nutrition 45, 713.

Shen, D. C., Shieh, S. M., Fuh. M. M. T., Wu. D. A., Chen, Y. D. I. \& Reaven, G. M. (1988). Resistance to insulin-stimulated-glucose uptake in patients with hypertension. Journal of Clinical Endocrinology and Metabolism 66, 580-583. 
Sniderman, A., Shapiro, S., Marpole, D., Skinner, B., Teng, B. \& Kwiterovich, P. O. (1980). Association of coronary atherosclerosis with hyperapobetalipoproteinemia [increased protein but normal cholesterol levels in human plasma low density $(\beta)$ lipoproteins]. Proceedings of the National Academy of Sciences of the USA 77, 604-608.

Sparrow, D., Borkan, G. A., Gerzof, S. G., Wisniewski, C. \& Silbert, C. K. (1986). Relationship of body fat distribution to glucose tolerance. Results of computed tomography in male participants of the normative aging study. Diabetes 35, 411-415.

Stokes, J., Garrison, R. J. \& Kannel, W. B. (1985). The independent contributions of various indices of obesity to the 22-year incidence of coronary heart disease: the Framingham heart study. In Metabolic Complications of Human Obesities, pp. 49-57 [J. Vague, P. Björntorp, B. Guy-Grand, M. Rebuffé-Scrive and P. Vague, editors]. Amsterdam: Elsevier.

Storlien, L. H., Jenkins, A. B., Chisholm. D. J., Pascoe, W. S., Khouri, S. \& Kraegen, E. W. (1991). Influence of dietary fat composition on development of insulin resistance in rats. Relationship to muscle trigylceride and $\omega-3$ fatty acids in muscle phospholipids. Diabetes 40, 280-289.

Svedberg, J., Björntorp, P., Smith, U. \& Lönnroth, P. (1990). Free-fatty acid inhibition of insulin binding, degradation, and action in isolated rat hepatocytes. Diabetes $39,570-574$.

Swislocki, A. L. M., Hoffman, B. B. \& Reaven. G. M. (1989). Insulin resistance, glucose intolerance and hyperinsulinemia in patients with hypertension. American Journal of Hypertension 2, 419-423.

Terry, R. B., Page, W. F. \& Haskell, W. L. (1992). Waist/hip ratio, body mass index and premature cardiovascular disease mortality in US army veterans during a twenty-three year follow-up study. International Journal of Obesity 16, 417-423.

Thiébaud, D., DeFronzo, R. A., Jacot, E., Golay, A., Acheson, K., Maeder, E.. Jéquier, E. \& Felber, J.-P. (1982). Effect of long-chain triglyceride infusion on glucose metabolism in man. Metabolism 31, 1128-1136.

Thomas, C. D., Peters, J. C., Reed, G. W., Abumrad, N. N., Sun. M. \& Hill, J. O. (1992). Nutrient balance and energy expenditure during ad libitum feeding of high-fat and high-carbohydrate diets in humans. American Journal of Clinical Nutrition 55, 934-942.

Tikkanen, M. J. \& Nikkilä. E. A. (1987). Regulation of hepatic lipase and serum lipoproteins by sex steroids. American Heart Journal 113, 562567.

Tremblay, A. (1992). Human obesity: a defect in lipid oxidation or in thermogenesis? International Journal of Obesity 16, $953-957$.

Tremblay, A., Després, J.-P., Maheux, J., Pouliot, M.-C., Nadeau, A.. Moorjani, S., Lupien, P. J. \& Bouchard, C. $(1991 \mathrm{a})$. Normalization of the metabolic profile in obese women by exercise and a low fat diet. Medicine and Science in Sports and Exercise 23, 1326 1331.

Tremblay, A.. Lavallée, N., Alméras, N., Allard, L., Després, J.-P. \& Bouchard, C. (1991b). Nutritional determinants of the increase in energy intake associated with a high-fat dict. American Journal of Clinical Nutrition 53, 113- 1137.

Tremblay, A., Nadeau, A., Després, J.-P., St-Jean, L., Thériault, G. \& Bouchard, C. (1990). Long-term exercise training with constant energy intake. 2. Effect on glucose metabolism and resting energy expenditure. International Journal of Obesity 14, 75-84.

Tremblay, A.. Plourde, G., Després, J.-P. \& Bouchard. C. (1989). Impact of dietary fat content and fat oxidation on energy intake in humans. American Journal of Clinical Nutrition 49. 799-805.

Vague, J. (1947). [Sexual differentiation, a factor affecting the forms of obesity.] Presse Médicale 30, 339-340.

Vague. J. (1956). The degree of masculine differentiation of obesities: a factor determining predisposition to diabetes, atherosclerosis. gout, and uric calculous disease. American Journal of Clinical Nutrition 4, 20-34.

Van Itallic, T. B. (1979). Obesity: adverse effects on health and longevity. American Journal of Clinical Nutrition 32 (Suppl. 12), 27232733

Weinsier, R. L., Norris, D. J., Birch, R., Bernstein, R. S., Wang, J., Yang, M. U., Pierson, R. N. \& van Itallie, T. B. (1985). The relative contribution of body fat and fat pattern to blood pressure level. Hypertension 7 , $578-585$.

Weintraub, M. S., Rosen, Y., Otto, R., Eisenberg, S. \& Breslow, J. L. (1989). Physical exercise conditioning in the absence of weight loss reduces fasting and post-prandial triglyceride-rich lipoprotein levels. Circulation 79. 1007-1014.

Williams, P. T., Krauss, R. M., Vranizan, K. M. \& Wood, P. D. S. (1990). Changes in lipoprotein subfractions during diet-induced and exercise-induced weight loss in moderately overweight men. Circulation $81,12931304$.

Williams, P. T., Wood, P. D., Haskell, W. L. \& Vranigan, K. (1982). The effect of running milcage and duration on plasma lipoprotein levels. Journal of the American Medical Association 247, $2674-2679$.

Wilmore, J. H. (1983). Body composition in sport and exercise: directions for future research. Medicine and Science in Sports and Exercise 15, 21-31.

Wing. R. R. \& Jeffrey, R. W. (1979). Outpatient treatment of obesity: a comparison of methodology and clinical results. International Journal of Obesity 3, 261.

Wing, R. R., Shoemaker, M., Markus, M. D., McDermott, M. \& Gooding. W. (1990). Variables associated with weight loss and improvements in glycemic control in type Il diabetic patients in behavioral weight control programs. International Journal of Obesity 14, 495503.

Wood, P. D., Haskell, W. L., Blair, S. N., Williams, P. T., Krauss, R. M., Lindgren, F. T., Albers, J. J., Ho, 
Changes in plasma lipids and lipoproteins in overweight men during weight loss through dieting as compared with exercise. New England Journal of Medicine 319. 11731179.

Wood, P. D. \& Stefanick, M. L. (1988). Exercise, fitness and atherosclerosis. In Exercise, Fitness and Health. A Consensus of Current Knowledge, pp. 409-420 [C. Bouchard, R. J. Shephard, T. Stephens, J. R. Sutton and B. D. McPherson, editors]. Champaign, IL: Human Kinetics Publishers.

Zurlo, F., Lillioja, S., Esposito-Del Puente, A.. Nyomba, B. L., Raz. I., Saad, M. F., Swinburn, B. A., Knowler, W. C., Bogardus, C. \& Ravussin, E. (1990). Low ratio of fat to carbohydrate oxidation as predictor of weight gain: study of 24-h RQ. American Journal of Physiology 259, E650 E657. 